\title{
The Diet Patterns of Diabetes Mellitus Patients in Lhokseumawe, Aceh Province, Indonesia
}

\author{
Zulfan Haris ${ }^{1}$, Siti Zahara Nasution ${ }^{2}$, Cholina Trisa Siregar ${ }^{3}$ \\ ${ }^{1}$ Arun Hospital, Lhokseumawe, Aceh \\ ${ }^{2,3}$ Faculty of Nursing, Universitas Sumatera Utara, Medan, Indonesia
}

\begin{abstract}
Diabetes Mellitus/DM is an increase in blood glucose levels or hyperglycemia which causes various complications in some important organs such as eyes, kidneys, nerves, and blood vessels. A proper diet of diabetes mellitus patients is determined based on the amount of food intake, scheduled meal, and daily food composition. This study is a descriptive research, and aim to identify the diets of diabetic patients in Pusong, Lhokseumawe with 108 in population. The number of research samples were 52 respondents using purposive sampling techniques. The sample criteria applied with several conditions, such as had been suffering from type 2 DM for more than 5 years and able to read and write in Indonesian. Data were collected using a validated and reliable questionnaire with a Cronbach alpha test value of 0.841 . The results showed that $78.8 \%$ of respondents were not able to control the type of daily food consumption, $73.1 \%$ were not able to control the amount of daily food, $67.3 \%$ were not able to obey the scheduled meal and $72.2 \%$ of the respondents were adhere to a daily diet. According to this research result, it is important to identify the factors that contribute to the diet of patients with diabetes mellitus in the future.
\end{abstract}

Keywords: diabetes mellitus diet, blood glucose, hyperglycemia

Received 10 June 2020 | Revised 26 June 2020 | Accepted 27 June 2020

\section{Introduction}

Diabetes mellitus is a condition of the body's inability to process glucose into cells and leads to an increase in blood sugar levels [1]. It impacts some chronic complications. Patients with mild glucose intolerance disorders continue to have the risk of metabolic diabetes. Patients with diabetes mellitus by $75 \%$ can occur complications in blood vessels resulting in death, heart attack, kidney failure, stroke, and gangrene and blindness. Decreased health of patients with diabetes mellitus resulted in addition to resulting in physical changes also resulted in economic changes, increased medical costs, and lost income (2). Symptoms such as frequent urination, increased thirst, increased appetite often occur in patients, and early signs of the disease Putro (2012).

WHO in 2000 stated that the number of Diabetes Mellitus patients in Indonesia is increase from 8.4 million to 21.3 million in 2030. The high number of people with diabetes mellitus makes Indonesia the fourth highest country in the world, after the United States, India, and China. The increase in the number of people with diabetes mellitus is caused by the increasing cases of 
obesity, lack of physical activity, less of fibrous food consumption, smoking, and consuming high-fat foods. The risk factors lead to diabetes mellitus occurrence involve some factors such as age, and age is an important factor in the occurrence of DM due to decreased physiology of the body. Epidemiological studies in various populations, the prevalence of diabetes mellitus show a specific increase with the increasing age of a person [4]. The increase in DM in developing countries is caused by changes in diet, from healthy foods to fast food, not high in fiber, high in fat, and high in calories. Foods that contain calories such as carbohydrates, fat, red meat consumed no longer follow a healthy diet. Consumption of animal foods and saturated fatty acid intake in South and Southeast Asian countries has increased significantly from the previous few years [5]. Data from Riskesda in 2003 showed that the prevalence of diabetes mellitus in urban areas reached 14.7\%, increasing the number of sufferers of Diabetes Mellitus became a serious threat and the number seven cause of death in the world [6].

Data from the Mon Geudong Health Center, Lhokseumawe showed that the total number of patient visits from January to 20 May 2013 was 1,067 people. It showed 13\% people with Diabetes Mellitus. The prevention of increasing cases of diabetes mellitus can be done with diet, exercise, monitoring, therapy, and education [1]. The main obstacle in managing the Diabetes Mellitus diet is the non-compliance caused by the patient's saturation of a limited diet or other reasons. Noncompliance could harm the patient's health status if the food consumed is not controlled [7]. Good management such as monitoring the diet by following dietary therapy can control the increase in insulin that is not controlled. Diabetes diets that can be done are to consume sugar-free foods and hydration exchange diets. The type of diet that is applied to someone with diabetes depends on the severity of the disease, accompanying complications, type of treatment, and way of life of the sufferer. A good and maintained diet can affect blood sugar levels in diabetics [8]. Diet patterns that can be applied include setting the type of food, the amount of food eaten every day, and eating schedule.

\section{Research Methods}

The design of this study is descriptive, which aims to identify the dietary patterns of patients with diabetes mellitus in Lhokseumawe, Aceh. The population in this study was 108 diabetes mellitus patients who visited the clinic from January to June 2013. Sampling was carried out in September 2013 using a purposive sampling technique with inclusion criteria: people with diabetes mellitus for more than 5 years, able to communicate, be able to read and write and be willing to be a respondent and type $2 \mathrm{DM}$. The number of samples of this study was $40 \%$ of the population, amounting to 52 people. This research is voluntary without coercion from other parties, if the respondent refuses to be investigated then the researcher will not force and continue to respect the rights of the respondents. the researcher will not enter the name of the respondent on the data collection sheet. Researchers maintain the confidentiality of information provided by respondents. The research instrument used was a questionnaire containing 
questions to identify compliance with people with diabetes mellitus in adopting dietary patterns. The questionnaire consisted of 25 questions to describe the diet, the amount of food, the type of food, the eating schedule of people with diabetes mellitus. The question was modified with an instrument model from the research of Nurul Haflah (2005) and The Medical Outcomes Study (MOS) Measure of Patient Adherence from Hays. Likert questionnaires consist of answer choices never, sometimes, often, and always. Positive questions that answer choices are always given a value of 4 , often with a value of 3 , sometimes given a value of 2 and never given a value of 1 . A negative question is always given a value of 1 , often with a value of 2 , sometimes given a value of 3 and not yet given a value of 4. Questionnaire results controlled between 63-100, and if not controlled 1-62. The validity test of the questionnaire was conducted by community department lecturers and the Basic Nursing Department who were experts in the field of diabetes mellitus. The reliability test was conducted with 25 respondents using Cronbach alpha. The reliability test value is 0.841 , where the reliability test results are greater than the table value of 0.70 , then the reliability questionnaire will be used. Analysis of the data used in this study uses a frequency distribution that aims to find a picture of people's diets in Lhokseumawe.

\section{Result and Discussion}

The results of the study obtained demographic data from 52 respondents, namely: The sex of the respondents most women by $69 \%$ (36 people), the highest age of suffering from diabetes mellitus in the range (40-60 years) amounted to $46.2 \%$ (24 people), respondents who married at $80.8 \%$ (42 people), the highest education is high school at $46.2 \%$ ( 24 people), the highest occupation is selling at $42.3 \%$ ( 22 people), the highest respondent income between 500.000 Rupiahs-2.000.000 rupiahs of $63.4 \%$ (33 people).

Table 1. Frequency Distribution of Respondents Demographic Data In Pusong Village, Lhokseumawe City $(\mathrm{n}=52)$

\begin{tabular}{l|c|c}
\hline Demographic Data & Frequency & Percentage (\%) \\
\hline Sex: & & \\
Male & 16 & 31 \\
Female & 36 & 69 \\
Age: & 20 & 38,8 \\
$25-40$ & 24 & 46,2 \\
$40-60$ & 8 & 15,4 \\
$>60$ & 42 & 80,8 \\
Status: & 9 & 17,3 \\
Married & 1 & 1,9 \\
Widow/widower & & 15.4 \\
Not married & 8 & 32,7 \\
Education: & 24 & 46,2 \\
Primary & 3 & 5,8 \\
Junior high & & \\
Senior high & 47 & 90,4 \\
College & 4 & 7,7 \\
Tribes: & 1 & 1,9 \\
Acehnese & & \\
Javanese & & \\
Malay & &
\end{tabular}




\begin{tabular}{l|c|c}
\hline Occupation: & 4 & 7,7 \\
Government & 4 & 7,7 \\
Private & 7 & 13,5 \\
Entrepreneur & 22 & 42,3 \\
Traders / selling & 10 & 19,2 \\
Fisherman & 5 & 9,6 \\
Others & 33 & 63,4 \\
Income in Rupiahs: & 19 & 36,6 \\
500.000-2.000.000 & & \\
>2.000.000 & & \\
\hline
\end{tabular}

Table 2 illustrates the type of food consumed by respondents the highest daily i.e. respondents cannot control the type of food that is equal to $78.8 \%$ (41 people), while those who can control the type of food consumed is $21.2 \%$ (11 people).

Table 2. Frequency Distribution and Percentage of Types of Food Consumed

\begin{tabular}{l|c|c}
\hline Type of food & f & \% \\
\hline Uncontrolled & 41 & 78,8 \\
Controlled & 11 & 21,2 \\
\hline Total & $\mathbf{5 2}$ & $\mathbf{1 0 0}$ \\
\hline
\end{tabular}

Table 3 illustrates The highest amount of food consumed by respondents is that respondents can control the amount of food consumed by respondents by $73.1 \%$ (38 people), while respondents who are unable to control the amount of food consumed is $26.9 \%$ (14 people).

Table 3. Frequency Distribution and Percentage of Diabetes Diet Pattern

\begin{tabular}{l|c|c}
\hline Amount of food & f & \% \\
\hline Uncontrolled & 14 & 26,9 \\
Controlled & 38 & 73,1 \\
\hline Total & $\mathbf{5 2}$ & $\mathbf{1 0 0}$ \\
\hline
\end{tabular}

Table 4 illustrates the highest meal schedule of respondents, namely respondents who were able to control the time to eat by $67.3 \%$ (35 people) and respondents who were unable to control the time to eat by $32.7 \%$ (17 people).

Table 4. Frequency Distribution and Percentage of Meal Schedule

\begin{tabular}{l|c|c}
\hline Meal Schedule & F & \% \\
\hline Uncontrolled & 17 & 32,7 \\
Controlled & 35 & 67,3 \\
\hline Total & $\mathbf{5 2}$ & $\mathbf{1 0 0}$ \\
\hline
\end{tabular}

Table 5 illustrates the ability of respondents to follow the highest dietary pattern that is, respondents were able to control dietary patterns by $72.2 \%$ (37 people) and respondents who were unable to control their diet by $28.8 \%$ ( 15 people). 
Table 5. Frequency Distribution and Percentage of Respondents in Adherence to Dietary Pattern

\begin{tabular}{l|c|c}
\hline Adhering To Dietary Pattern & F & \% \\
\hline Adhering to a dietary & 37 & 72,2 \\
Not adhere to a dietary & 15 & 28,8 \\
\hline Total & $\mathbf{5 2}$ & $\mathbf{1 0 0}$ \\
\hline
\end{tabular}

Blood sugar levels in diabetics are affected by dietary patterns (Susanti \& Bistara, 2018; Rahmawati, 2011). Patients with uncontrolled blood sugar levels will have a higher risk of developing diabetes mellitus. Eating patterns that are well controlled by the patient can be done by adjusting the number of food frequencies, eating schedule, and daily food composition or type of food in diabetics at home.

\section{Types of Food}

The results of this study obtained data that respondents could not control the type of food by $78.8 \%$ (41 people). The results of this study are in line with the results of a study conducted by Rahmawati (2011) who examined the relationship of diets, especially on the right types of food in diabetics in maintaining blood sugar levels in RSUD Dr. Wahidin Sudirohusodo Makassar in 2011 obtained data that $87.9 \%$ of respondents could not control the type of food consumed daily. This condition is accordance with the habits of the people of Aceh who are synonymous with happy eating sweet foods and drinks. The results of this study obtained data as many as 47 people (90.4\%) of the research respondents were Acehnese. The assumption of researchers, the people of Aceh have a culture that likes to make food from ingredients that contain high carbohydrate and sugar, and the Aceh region is an area that is identical with culinary which causes people to tend to violate the type of healthy food that must be consumed for people with diabetes mellitus. Nur, Fitria, Zulhaida, \& Hanum, 2016 researched the relationship between consumption patterns of the people of Aceh and diabetes mellitus in RSUD dr. Fauziah Bireuen Aceh Province. The study explained that the sweet foods commonly consumed by the Acehnese people were dodoi, meuseukat, and rich asoe which are typical foods of Aceh. The results of the study stated that respondents with Diabetes Mellitus who consumed sweet foods by $50 \%$. Sugary foods are foods that contain sugar. Sugar consumed can determine the speed of an increase in blood sugar levels. High blood sugar levels need to be adjusted to avoid the glycemic index continuously. Foods that can accelerate the increase in the glycemic index quickly such as sugar, honey, syrup, bread, noodles, and rice.

Foods that contain high glucose are not recommended for diabetics, because these foods can increase blood sugar levels. The results of the Mayer et.al, 2015 study of food insecurity, coping strategies, and glucose control in low-income patients with high-glucose food consumption obtained results that there is a relationship between food insecurity with poor glucose control by 
$40.5 \%$. This explains that the type of food consumed by diabetics is also affected by their income, the level of purchasing ability of a person results in the person not controlling the type of food that is healthy or unhealthy for consumption. The results of this study illustrate that the highest income of respondents is below Aceh's minimum wage of $63.4 \%$. Monthly income also affects the dietary behavior of people with diabetes mellitus (Muhaburra, 2014; Putra, 2015). The ability to prepare healthy food is the main reason that causes the malfunctioning of the patient's diet in consuming daily food (Mubarti, 2012).

According to research by Savoca \& Miller (2001) that people with diabetes mellitus are easily tempted by the types of foods commonly eaten before suffering from diabetes mellitus which includes high-fat foods, red meat, sweets, desserts, starches, and beverages. Changing the type of food eaten will be difficult and respondents in this study also said they were lazy to eat fruits because of low sugar content. The same research was conveyed by Rivellese, Boemi, Cavalot, Costalgliola, \& Feo (2008) adherence to the diet in patients with Diabetes Mellitus was not entirely satisfactory in parts considered important in the consumption of carbohydrates, saturated fats, and fiber. Lack of a patient's ability to control the type of diet consumed can be influenced by the lack of knowledge about awareness of healthy living in consuming low-sugar foods such as fruits, vegetables, and the patient does not know the types of foods that contain low sugar. This is supported by Sonyo, Hidayati, \& Sari (2016) who researched the knowledge and attitudes of type of eating arrangements for DM type 2 patients in the Kendal Puskesmas 02 work area stating that respondents lack knowledge about the type of seating arrangements in accordance with DM type 2 .

According to Rahmawati (2011) who examined dietary planning for people with diabetes mellitus in polyclinic at Dr.H. Moch Ansari Saleh Banjarmasin, a nutritionist in determining the menu needed setting food types, variations based on one's eating habits, types of food that can easily be found, balanced, and as needed, but almost all types of food as a cause of diabetes mellitus when consumed in excessive amounts. The types of fruit that must be avoided are sapodilla, sweet orange, pineapple, rambutan, durian, jackfruit, and grapes. The recommended types of fruit are papaya, banana (except plantain, golden banana, banana horn), apple, tomato, watermelon.

\section{Amount of Food}

The results of the study obtained data that respondents can control the amount of food consumed by $73.1 \%$ (38 people), while respondents who cannot control the amount of food are $26.9 \%$ (14 people). The results of this study contradict the results of a study conducted by Rosaline (2011), which examined the amount of food that is suitable for people with diabetes mellitus in their daily lives at the clinic in Semarang Hospital in 2011, 42 data or $80.7 \%$ were obtained. control the amount of food, and 10 people or $19.3 \%$ can control the amount of food. 
According to the researchers' assumptions, the patient's ability to control the amount of food that has not reached its entirety can be due to a lack of knowledge about the number of nutrients present in food. Magdalena research results, 2016 DM patients are not good at applying the amount of food in accordance with the disease resulting in an increase in blood sugar levels by 50 patients $(52 \%)$.

The amount of food consumed by diabetics must be as needed to reach normal blood sugar levels. But sometimes the amount of energy intake can exceed or be less than what is needed. Nasution, Jumirah, and Siregar's research in 2013 on the description of the diet of outpatients with diabetes mellitus at the health center in Kotanopan, Mandailing Natal in 2013 explained that the energy intake consumed by diabetics consumes more food not according to need. Excessive food consumption and less than needs can result in changes in blood sugar levels of patients with diabetes mellitus Nurhidayat (2017). Based on research from Idris, Jafar, \& Indriasari (2014) data obtained that type 2 DM patients who have less carbohydrate intake than needed tend to be unable to control blood sugar levels compared to patients whose carbohydrate intake is as needed.

Consumption of an uncontrolled amount of food can be influenced by increased hunger or polyphagia. Polyphagia causes people with type 2 diabetes will always feel hungry because the calories produced from food will be metabolized into glucose in the blood and not all of them can be utilized in the body. The amount of food needs to consider several factors such as gender, age, activity, and nutritional status. Arrangements for the amount of food in accordance with the dietary standards of DM patients consist of carbohydrates $45-65 \%$ of energy needs, protein $10-20 \%$ of energy needs, fat $20-25 \%$ of energy needs, and pure sugar $<5 \%$ of energy need Mubarti (2012).

\section{Scheduled Meal}

The results obtained by the highest data that respondents were able to adhere to an eating schedule that is in accordance with health by $67.3 \%$ ( 35 people). The results of this study are not in line with the results of a study conducted by Rosita (2013) who examined the risk factors associated with blood sugar levels in type 2 diabetes mellitus patients in Karang Anyar District Hospital obtained data of 55 respondents (76.4\%) not can control their eating schedule and 17 respondents $(23.6 \%)$ can control their eating schedule. According to the assumption that the accuracy of the eating schedule of diabetics can be influenced by many factors such as knowledge, occupation, and information obtained. The ability of respondents to adhere to a meal schedule in this study can also be caused by the majority of respondents working sales at $42.3 \%$ tax making it easier for respondents to be on time eating. When someone is busy with his work, it is very rare for someone to pay attention to his eating schedule, which causes his eating schedule to be out of control. the results of this study are in line with Mubarti (2012) who 
examined the influence of nutritional education on knowledge, diet, and blood glucose levels of patients with diabetes mellitus in Pasewang Lantok at Jeneponto District Hospital, found as many as 18 respondents (53.3\%) controlled eating schedule and 12 respondents (46.7\%) uncontrolled eating. Diabetic patients' eating schedules must match intervals every 3 hours. Diabetes mellitus diet is given by means of 3 meals interspersed with a distance of 3 hours.

Muchtasar (2012) who examined the relationship between diabetes knowledge and social support with diabetic retinopathy behaviour in diabetics Mellitus in the public hospital Prof.dr.Margono Purwokerto, usually women are able to provide food independently, and follow the rules given by health workers rather than Men. Eating arrangements in women have an effect on diet compliance, especially on cholesterol, Zanetti, et al, (2015). This is in accordance with the opinion of Lubis (2006) who examined the social support of patients with terminal kidney failure who carry out indirectly Women's therapy directed to trust external responses, so that they are more obedient and dependent on medical personnel rules. The hadith narrated by the Prophet said, means we are people who do not eat except after being hungry, and when we eat not full. The purpose of the Prophet's own hadith is to order to regulate food and to uphold ethics. It is clear that every individual must adhere to the eating schedule needed by the body to maintain balance and health. This is certainly suitable for people with diabetes mellitus because people with diabetes mellitus have a tendency to change blood sugar levels significantly. blood sugar levels will be high after eating and for some time not getting food intake directly causes blood sugar levels to below. Eating on time for people with diabetes mellitus with the principle of small portions at a certain time or eating before being hungry and stopping before satiety can prevent hypoglycemia and hyperglycemia, so with small but frequent portions, carbohydrates will be digested and absorbed more slowly and stably. Insulin requirements also become lower and insulin sensitivity increases so that the body's metabolism can run better (Febriana, 2014).

\section{Diabetes Diet Patterns}

The results of the study obtained data that respondents had the ability to follow a diet pattern of $72.2 \%$ (37 people) and respondents who were unable to control their diet by $28.8 \%$ (15 people). The results of this study are in line with research conducted by Putro (2012) who examined the proper dietary patterns of patients with diabetes mellitus at the Kediri General Hospital obtained data of $63.3 \%$ controlled amount of food and $36.7 \%$ amount of uncontrolled food. Al-Qur'an verse AT-Thoha verse 81 which means eating between the good fortune we have given you, and not exceeding that limit.

The results of other studies that are not in line with this study, conducted by Nurul (2005), who studied the level of adherence to the diabetes mellitus diet at the endocrine clinic at Pirngadi Hospital in Medan obtained data of patients who were not adherent to the diet of $77.8 \%$ and 
patients who adhered to a diet of $22.2 \%$. Research from Febriana (2014) amounting to $68.8 \%$ of respondents did not adhere to the diabetes diet. The level of adherence of patients with diabetes mellitus in implementing a diet is very low. Patients who do not adhere to the diet are affected by adherence to diet consumption, past situational factors such as psychological and social pressure to eat. According to Almatzier (2010), the number of calories consumed in a day is used to meet the body's calorie needs. factors that need to be considered in regulating diet are determining total calories, daily food composition specified in percentage. Male calorie needs are more than female, carbohydrate, protein, and fat between men and women are different.

According to Nurul (2005), a person being obedient or disobedient to the recommended diet and treatment program is influenced by predisposing factors, supporting factors, and driving factors. Predisposing factors are the main factors that exist in individuals manifested in the form of knowledge, attitudes, beliefs, and beliefs and values. Besides, there are supporting factors that are factors outside the individual such as economic status/income, where income factors will affect an individual's lifestyle, support/attention and the role of the family in implementing a diet program, driving factors are strongly associated with factors that motivate individuals to go on a diet. Other external factors are the support of health workers, Fauzia, Sari \& Artini (2018). The results of research conducted by Yulia (2015) showed that factors that influence diet adherence in DM patients include education, knowledge, perception, motivation, family support, support of health workers, and long-suffering.

Communication between patients and health workers can affect the level of adherence of someone to adhere to the dietary pattern of patients with diabetes mellitus, for example, information and supervision from health workers in providing information about health. Nurhidayat Research (2017) examined the factors associated with adherence to diet management in patients with diabetes mellitus obtained data that good communication between health workers will facilitate the receipt of information by patients and patients will have an understanding of medical conditions, dietary patterns that must be implemented. Patient communication with obstructed health workers can be influenced by several factors to achieve patient compliance in regulating food patterns, lack of information, supervision, the dissatisfaction of care provided, and minimal frequency of supervision Utomo (2011).

Knowledge about diabetes mellitus management is related to the successful implementation of type 2 diabetes mellitus management (Dwipayanti, 2017). the successful implementation of DM management is related to patient compliance in applying the diabetic diet pattern (Bistara \& Ainiyah, 2018). this shows that people who have good knowledge will have a 4 times success rate in managing patients compared to those who lack knowledge. Patient's knowledge about diabetes mellitus is a tool that helps sufferers to manage diabetes throughout their lives through 
health workers, the more and the better the patient understands about the disease and diet that must be followed, the better the adherence to the diet (Husnah, 2016).

Food management of people with diabetes mellitus is one of the pillars in controlling blood sugar levels. Inaccurate information can be dangerous for diabetics. People with diabetes mellitus often get a false information about diabetes foods. Health workers should provide good and correct information to people with diabetes mellitus. Research from Husnah (2016) at the Ulee Kareng Health Center in Banda Aceh obtained data that $87 \%$ of respondents stated that they had not received education about diet from health workers. This condition can affect the diet of people with diabetes mellitus. Increased promotion of dietary patterns for Diabetes mellitus patients in adhering to dietary patterns requires knowledge and family support (Gustina, Suryati, \& Heryati, 2014). Nurhidayat (2017) stated that factors related to compliance with diet management in diabetes mellitus patients who get the result that family support will affect adherence to the dietary patterns of people with diabetes mellitus. Research by Sugandi, Hasneli \& Bayhakki (2018) showed that family support will provide good coping for other family members. Support can be given in the form of supervision and help go on a diet.

Dietary management for people with diabetes mellitus is done for life so that dieting becomes something very boring for patients. Patients do not understand, do not have a strong awareness in maintaining health and low motivation can result in uncontrolled dietary patterns (Jaworski, Panczyk, Cedro, \& Kucharska, 2018). Motivation has a very big role in shaping the behavior of people with diabetes mellitus including adherence to the diet. So without motivation in diet regulation, patients with diabetes mellitus will experience non-compliance in regulating their daily diet (Gustina, Suryati, \& Heryati, 2014). Adherence to a diabetic diet is also influenced by the self-acceptance of the disease. Self-acceptance of disease is not a major factor because social support from the immediate environment and education about diet is also very influential on adherence to dietary patterns (Jaworski, Panczyk, Cedro, \& Kucharska, 2018). Compliance in carrying out dietary patterns will change when attending gatherings with friends and family serving food, so that $\mathrm{m}$ becomes an obstacle to the implementation of diet management (Jadawala, Pawar, Patel, Patel \& Bansal, 2017). Indonesians especially in Aceh have various kinds of habits that will be implemented and will not be separated by eating together. Inviting eating when guests come and attend invitations is considered impolite if not serving food, even if only modestly.

\section{Conclusion}

Based on the results of the study found that there are still many people with diabetes mellitus who have not followed the diabetes diet. Therefore, health workers are expected to conduct 
counselling to the community at the Mon Geudong Community Health Center in Pusong Village to increase their knowledge directly to the community.

\section{Acknowledgement}

Author would like to thank the respondents for all valuable data provided in this research.

\section{Conflict of Interest}

There is no conflict of interest in this research result.

\section{REFERENCES}

[1]

Smeltzer, (2002).Keperawatan Medikal Bedah, Edisi kedelapan,Vol kedua, Jakarta: EGC.

Price. (2005).Patologi Konsep Klinis Proses-Proses Penyakit, Edisikeenam. Jakarta: EGC

Putro (2012).Pola Diet Tepat Jumlah, Terhadap Kadar Gula Darah Pasien Diabetes Melitus di Rumah Sakit Umum Kediri. http://journal.kesehatan.ac.id

Azrimaidaliza, (2011). Asupan Gizi dan Penyakit Diabetes Mellitus. Jurnal Kesehatan Masyarakat, 6(3). jurnal.fkm.unand.ac.id

Muchtasar (2012).Hubungan Antara Pengetahuan Diabetes dan Dukungan Sosial Dengan Perilaku Retinopati Diabetik pada Penderita Diabetes Melitus Di Prof.Dr. Margono Rumah Sakit Umum Purwokerto.

Riset Kesehatan Dasar (RISKESDAS). http://www.mediacastore.com/lapriskesdas/.pdf.

Fauzia, Y., Sari, E., \&Artini, B. (2018). Gambaran factor-faktor yang mempengaruhi kepatuhan Diet Penderita Diabetes Mellitus di Wilayah Puskesmas Pakis Surabaya. Jurnal.http://ejournal.stikeswilliambooth.ac.id

Rudi, A. \&Kwureh, H.N. (2017). Faktor risiko yang mempengaruhi kadar gula darah puasa pada pengguna layanan laboratorium. Wawasan kesehatan 3(2). ISSN : 2087-4995

Susanti \& Bistara, D. N. (2018). Hubungan Pola Makan dengan Kadar Gula Darah pada Penderita Diabetes Melitus. Jurnal Kesehatan Vokasional, 3(1). http://journal.ugm.ac.id/jkesvo

Rahmawati. (2011). Hubungan Pola Makan Khususnya Pada Jenis Makanan yang Tepat pada Penderita Diabetes Melitus dalam Menjaga Kadar Gula dalam Darah di RSUD Dr. Wahidin Sudirohusodo Makasar. http://Journal.unhas.ac.id

Nur, A., Fitria, E., Zulhaida. A. \& Hanum, S. (2016). Hubungan Pola Konsumsi dengan Diabetes Melitus Tipe 2 pada Pasien Rawat Jalan di RSUD Dr. Fauziah Bireun Provinsi Aceh. Media Litbangkes, 26(3).

Mayer, V. L., McDonough, K., Seligman, H., Mitra, N., \& Long. J. A. (2015). Food Insucurity, Coping Strategies and Glucose control in low-income Patients with Diabetes. Public Health Nutrition, 19(6). https://www.ncbi.nlm.nih.gov/pubmed 
[13] Primanda, Y. Kritpracha, C. \&Thaniwattananon, P. (2011). Dietary Behaviours among Patients with Type 2 Diabetes Mellitus in Yogyakarta, Indonesia. Nurse Media Journal of Nursing 1(2). https://ejournal.undip.ac.id

[14] Putra, K. W. R. (2015). Factor Influencing Eating Behaviours Among Type 2 Diabetes Mellitus Patients in Sidoarjo Sub-District, East Java, Indonesia. Thesis. Burapha University

[15] Muhaburra, M. B. (2014). Prevalence and factors associated with non adherence to diet and exercise lifestyle recommendations among type 2 diabetes patients. Thesis. University of Nairobi

[16] Sacova, M., \& Miller, C. (2001). Food Selection and Eating Patterns: Themes Found among People with Type 2 Diabetes Mellitus. Journal of Nutrition Education, 33. http://www.sciencedirect.com/science/journal/00223182

[17] Rivellese, A. A., Boemi, M., Cavalot, F., Costalgliola, L., Feo, P. D.,et all. (2008). Dietary habits in Type II Diabetes Mellitus: How is Adherence to Dietary recommendations?.European Journal of Clinical Nutrition.http://www.siditalia.it/jdownloads/mindit/mind_rivellese_2008.pdf

[18] Suprihatin. (2012).Pola Diet Tepat Jumlah, Jadwal, dan Jenis Terhadap Kadar Gula Darah Pasien Diabetes Melitustipe II di Instalasi Rawat Jalan Rumah Sakit Baptis Kediri.http://journal.stikes.ac.id

[19] Sonyo, S.H., Hidayati, T., \&Sari,N. K. (2016). Gambaran pengetahuan dan sikap pengaturan makan penderita DM Tipe 2 di Wilayah KerjaPuskesmas Kendal 02. Jurnal Care, 4(3). https://jurnal.unitri.ac.id

[20] Magdalena, C. (2016). Hubungan Penerapan 3J (Jumlah, Jenis, dan Jadwal) dan Aktivitas Fisik Terhadap Status Kadar gula Darah pada Penderita Diabetes Mellitus Tipe 2 di Posbindu Wilayah Kerja Puskesmas Ciputat. Skripsi. Universitas Islam Negeri Syarif Hidayatullah

[21] Idris, A. M., Jafar, N., \&Indriasari, R. (2014). Polamakan Kadar gula Darah Pasien DM Tipe 2. Jurnal MKMI. http://journal.unhas.ac.id

[22] Nurhidayat, I. (2017). Faktor-faktor yang Berhubungan dengan Kepatuhan Penatalaksanaan Diet pada Pasien Diabetes Melitus. Skripsi.http://repository.umy.ac.id

[23] Mubarti (2012).Pengaruh Edukasi Gizi Terhadap Pengetahuan, Pola Makan dan Kadar Glukosa Darah Pasien Diabetes Melitus RSUD lantok pasewang jeneponto.http://journal.kesmas.ac.id

[24] Muchtasar (2012).Hubungan Antara Pengetahuan Diabetes dan Dukungan Sosial Dengan Perilaku Retinopati Diabetik pada Penderita Diabetes Melitus Di Prof.Dr. Margono Rumah Sakit Umum Purwokerto

Zanetti, M. L., Arrelias, C. C. A., Franco, R. C., Santos, M. A., Rodriques, F. F. L., \&Faria, H. Y. G. (2015). Adherence to Nutritional Recommendations and Sociodemographic Variables in Patients with Diabetes Mellitus. Journal of School of Nursinghttp://www.scielo.br/pdf/reeusp/v49n4/0080-6234-reeusp-49-040619.pdf

[26] Lubis (2006).Dukungan Sosial pada Pasien Gagal Ginjal Terminal yang MelakukanTerapi. Tesis, Universitas Sumatera Utara, Medan. http://repository.usu.ac.id 
[27] Perkumpulan Endokrinologi Indonesia (PERKENI). (2011). Konsensus Pengendalian dan Pencegahan Diabetes Mellitus Tipe2 di Indonesia 2011. http://pbperkeni.or.id

[28] Febriana, R. (2014). Hubungan Kepatuhan Diit dengan Kadar Gula Darah Sewaktu pada Pasien Diabetes mellitus Tipe 2 di Rawa Inap RSUD Sukoharjo. Skripsi .Universitas Muhammadyah Surakarta

[29] Faktor yang mempengaruhi kepatuhan Diet Penderita Diabetes Mellitus di Wilayah Puskesmas Pakis Surabaya. Jurnal.http://ejournal.stikeswilliambooth.ac.id

[30] Yulia, S. (2015). Faktor-faktor yang Mempengaruhi Kepatuhan dalam Menjalankan Diet pada Penderita Diabetes Mellitus Tipe 2. Skripsi. Universitas Negeri Semarang

[31] Nurhidayat, I. (2017). Faktor-faktor yang Berhubungan dengan Kepatuhan Penatalaksanaan Diet pada Pasien Diabetes Melitus. Skripsi. http://repository.umy.ac.id

[32] Saifunurmazah, D. (2013). Kepatuhan Penderita Diabetes Mellitus dalam Menjalani Terapi Olahraga dan Diet. Skripsi. Universitas Negeri Semarang

[33] Utomo, A. Y. S. (2011). Hubungan antara 4 Pilar Pengelolaan Diabetes Melitus dengan Keberhasilan Pengelolaan Diabetes Melitus Tipe 2. Skripsi. Universitas Diponegoro

[34] Dwipayanti, P.I. (2017). HubunganPengetahuantentang Diet Diabetes Mellitus dengan Kepatuhan Pelaksanaan Diet pada Penderita Diabetes Mellitus. Jurnal Keperawatan \& Kebidanan. https://jurnalonline.lppmdianhusada.ac.id

[35] Bistara, D. N. \&Ainiyah, N. (2018). Hubungan Pengetahuan dengan Kepatuhan Diet pada Penderita Diabetes Melitus di Posyandu Lansia Cempaka Kelurahan Tembok Dukuh Kecamatan Bubutan Surabaya. Jurnal Ilmiah Kesehatan, 13(1). https://journal.unusa.ac.id

[36] Usnah. (2016). Gambaran Dietetik Penderita Diabetes Melitus di Puskesmas Ulee Karenga Banda Aceh. Jurnal Kedokteran Syiah Kuala, 16(3).

Nurhidayat, I. (2017). Faktor-faktor yang Berhubungan dengan Kepatuhan Penatalaksanaan Diet pada Pasien Diabetes Melitus. Skripsi.http://repository.umy.ac.id

[38] Gustina, Suryati, \&Heryati. (2014). Faktor-faktor yang Berhubungan dengan Kepatuhan Diet Diabetes Mellitus padaPasien DM. JKep, 2(3). ejurnal.poltekkesjakarta3.ac.id

[39] Fauzia, Y., Sari, E., \& Artini, B. (2018). Gambaran faktor-faktor yang mempengaruhi kepatuhan Diet Penderita Diabetes Mellitus di Wilayah Puskesmas Pakis Surabaya. Jurnal.http://ejournal.stikeswilliambooth.ac.id

[40] Sugandi, A., Hasneli, Y., \&Bayhakki. (2018). Faktor-faktor yang Mempengaruhi Kepatuhan Diet Diabetes pada Pasien Diabetes Mellitus Tipe 2. Jurnal. https://jom.unri.ac.id

[41] Jaworski, M., Panczyk, M., Cedro, M., \&Kucharska, A. (2018). Adherence to Dietary Recommendations in Diabetes Mellitus: Disease Acceptance as a Potential Mediator. Journal: Patient Preference and Adherence 
[42] Jadawala, H. D., Pawar, A. B., Patel, P. B., Patel, S. B., \& Bansal, R. K. (2017). Factors Associated with Non Adherence to Diet and Physical Activity among Diabetes Patients: A Cross Sectional Study. National Journal of Community Medicine, 8(2).

[43] Patro, S., Adhya, A. K., Pal, P., Mishra, S. N., \&Charya, S. K. (2014). Study of dietary Patterns and risk profile among tha patient of Diabetes Mellitus in Bhubaneswar. International Jornalof Drug Development and Research, (6)4 